\title{
PENGATURAN PEMIDANAAN TERHADAP PECANDU DAN PENYALAH GUNA NARKOTIKA DALAM UNDANG-UNDANG NOMOR 35 TAHUN 2009 TENTANG NARKOTIKA
}

\author{
Gst. Ngurah Arya Dharma Susila, Fakultas Hukum Universitas Udayana, \\ e-mail arya.dharma08@gmail.com \\ Ida Bagus Surya Dharma Jaya, Fakultas Hukum Universitas Udayana, e-mail \\ suryadharma_62@yahoo.com
}

doi: https://doi.org/10.24843/KS.2020.v08.i10.p02

\begin{abstract}
ABSTRAK
Penelitian ini bertujuan menganalisis pengaturan tentang pecandu dan penyalahguna narkotika di dalam Undang-Undang Nomor 35 Tahun 2009 tentang Narkotika dan juga menganalisis tentang pemberian sanksi pidana bagi pecandu dan penyalah guna narkotika. Metode penelitian yang digunakan adalah metode penelitian hukum normatif dan menggunakan pendekatan perundang-undangan dan pendekatan analisis. Hasil dari penelitian ini adalah Pecandu dan penyalahguna narkotika diatur di dalam tujuan pembuatan Undang-Undang Nomor 35 Tahun 2009 tentang Narkotika, tepatnya pada Pasal 4 huruf d yang mewajibkan pecandu dan penyalahguna narkotika untuk direhabilitasi medis dan rehabilitasi sosial. Walaupun, Pasal 134 dan 127 ayat (1) mengatur bahwa pecandu dan penyalahguna dapat dikenakan sanksi pidana baik berupa pidana penjara, pidana kurungan, ataupun pidana denda. Namun, karena undangundang ini menganut double track system yang artinya ada sanksi pidana dan juga sanksi tindakan maka pecandu dan penyalahguna seharusnya diberikan sanksi tindakan berupa rehabilitasi medis dan rehabilitasi sosial.
\end{abstract}

Kata kunci: Pengaturan; Pecandu; Penyalahguna; Narkotika

\begin{abstract}
This paper aims to analyze the regulation of narcotics addicts and abusers in Law Number 35 Year 2009 regarding Narcotics and elaborate the provision of criminal sanctions for drug addicts and abusers. The research method used is a normative legal research method and the statutory approach and analysis approach. The results of this study were narcotics addicts and abusers arranged in the purpose of making Law Number 35 of 2009 regarding Narcotics, precisely in Article 4 letter d which requires drug addicts and abusers to be rehabilitated medically and socially rehabilitated. Although, Articles 134 and 127 paragraph (1) regulate that addicts and abusers may be subject to criminal sanctions in the form of imprisonment, confinement, or fines. However, because this law adheres to a double track system which means there are criminal sanctions and also sanctions for actions, addicts and abusers should be given sanctions in the form of medical rehabilitation and social rehabilitation.
\end{abstract}

Keywords: Regulation; Addict; Abuser; Narcotic

\section{Pendahuluan}

\subsection{Latar Belakang Masalah}

Narkotika merupakan zat atau juga dapat berbentuk obat mempunyai kegunaan membantu di dalam dunia pengobatan, bila digunakan sesuai takaran yang tepat. Takaran narkotika yang dokter berikan kepada pasiennya hanya bertujuan untuk 
membantu dalam dunia pengobatan. Penggunaan narkotika dalam dunia kedokteran pada umumya digunakan saat anestesi atau lebih dikenal saat dilakukan pembiusan sesaat sebelum dilakukannya operasi terhadap pasien.

Narkotika memiliki peraturan tersendiri yang mengaturnya di Indonesia. Peraturan tersebut adalah Undang-Undang Nomor 35 Tahun 2009 tentang Narkotika (selanjutnya disebut sebagai UU 35/2009). Definisi narkotika dalam Pasal 1 angka 1 UU 35/2009 pada intinya memuat tentang zat yang dapat menimbulkan beberapa efek salah satunya adalah menghilangkan nyeri, tetapi bukan hanya ada efek yang dapat menyembuhkan namun ada efek lain yang merugikan yaitu ketergantungan terhadap narkotika tersebut. Narkotika itu sendiri dipisah per golongan jenis-jenisnya yang terdiri dari 3 (tiga) golongan. Kegunaan narkotika setiap golongan dijelaskan dalam penjelasan Pasal 6 ayat (1) UU 35/2009. Narkotika pada golongan I tidak dapat digunakan untuk terapi karena menyebabkan ketergantungan yang sangat tinggi. Narkotika golongan II dapat digunakan dalam terapi tetapi hanya digunakan sebagai pilihan terakhir karena potensi ketergantungannya juga masih tinggi. Narkotika golongan III yang paling banyak digunakan untuk terapi karena potensi ketergantungannya yang ringan. Ketiga golongan tersebut memiliki persamaan yaitu digunakan untuk pengembangan ilmu pengetahuan.

Efek berbahaya dari narkotika itu sendiri telah ada pada definisi narkotika tersebut yaitu dapat menimbulkan ketergantungan. Efek ketergantungan akan muncul apabila pemakaiannya tidak sesuai dengan yang seharusnya. Hal ini semaki menjadi rumit dimana dosis penggunaannya akan semakin meningkat dan ketika penggunaannya dihentikan akan mengakibatkan kematian. ${ }^{1}$ Hal tersebut menjadi suatu penyalahgunaan narkotika oleh pihak yang tidak bertanggungjawab yang nantinya dapat memunculkan pecandu-pecandu narkotika di lingkungan masyarakat. Pecandu dan penyalah guna narkotika sering kali dianggap sebagai pelaku tindak kejahatan narkotika dalam masyarakat. Asumsi-asumsi dan anggapan-anggapan seperti itu yang membuat pecandu narkotika, penyalah guna narkotika ataupun keluarga mereka yang berusaha untuk mencari pertolongan berupa pengobatan menimbulkan rasa takut untuk melaporkan ke pihak yang menangani hal tersebut karena mereka takut dianggap sebagai pelaku kejahatan kemudian dimasukan ke dalam penjara.

Penelitian yang sebelumnya membahas tentang penyalah guna narkotika yaitu penelitian oleh Ida Bagus Putu Swadharma Diputra pada tahun 2013.² Permasalahan dalam penelitian tersebut mengenai pemberian sanksi rehabilitasi terhadap penyalah guna narkotika dan juga hambatan dalam memberikan sanksi rehabilitasi terhadap penyalah guna narkotika. Kemudian, penelitian lain yang membahas mengenai penyalahguna narkotika yaitu penelitian yang dilakukan oleh Fauzy Risky pada tahun 2017. 3 Penelitian tersebut merupakan penelitian hukum sosiologis yang permasalahannya mengenai penerapan dan kendala serta konsep ideal pelaksanaan rehabilitasi terhadap pecandu, penyalahguna dan korban narkotika berdasarkan Rekomendasi Tim Asesmen Terpadu di wilayah Hukum Badan Narkotika Nasional

1 Sudarto, Kapita Selekta Hukum Pidana, Cet. ke-IV, (Bandung, PT Alumni, 2010), 39.

2 Diputra, I. B. P. S. “Kebijakan Rehabilitasi Terhadap Penyalah Guna Narkotika Pada UndangUndang Nomor 35 Tahun 2009 Tentang Narkotika. Jurnal Magister Hukum Udayana (Udayana Master Law Journal), 2(1) (2013).

3 Rizky, F. Pelaksanaan Rehabilitasi terhadap Pecandu, Penyalahguna dan Korban Narkotika. Riau Law Journal, 1(1), 103-123. 
Provinsi Riau dalam praktek peradilan berdasarkan Pasal 127 Jo Pasal 54 UndangUndang Nomor 35 Tahun 2009 tentang Narkotika.

\subsection{Rumusan Masalah}

Berdasarkan latar belakang masalah yang ada, maka bisa ditentukan dua permasalahan pokok yang akan dikaji dalam tulisan ini, yaitu:

1. Bagaimanakah pengaturan mengenai pecandu dan penyalahguna narkotika dalam Undang-Undang Nomor 35 Tahun 2009 Tentang Narkotika?

2. Apakah berdasarkan Undang-Undang Nomor 35 Tahun 2009 Tentang Narkotika, pecandu dan penyalah guna narkotika dapat dipidana?

\subsection{Tujuan Penulisan}

Penulisan ini memiliki tujuan untuk menganalisis mengenai pengaturan terhadap pecandu dan penyalah guna narkotika dalam UU 35/2009 dan menganalisis mengenai ketentuan pidana bagi pecandu dan penyalah guna narkotika dalam UU 35/2009.

\section{Metode Penelitian}

Jenis metode dalam penelitian ini adalah metode penelitian hukum normatif. Soerjono Soekanto beserta Sri Mamuji memberikan definisi tentang penelitian hukum normatif, yang dimana artinya adalah penelitian hukum yang dilakukan dengan cara meneliti bahan pustaka atau data sekunder belaka. ${ }^{4}$ Penelitian ini menggunakan jenis pendekatan perundang-undangan (statue approach) dan jenis pendekatan analisis (analytical approach). Sumber bahan hukum yang digunakan terdiri dari bahan hukum primer, bahan hukum sekunder dan bahan hukum tersier. Bahan hukum primer yaitu UU 35/2009. Bahan hukum sekunder terdiri dari hasil penelitian ahli hukum dan doktrin-doktrin para ahli. Sumber hukum tersier terdiri dari kamus, ensiklopedia, dan lain-lain. ${ }^{5}$ Teknik pengumpulan bahan hukum menggunakan teknik studi dokumen. Metode analisis bahan hukum yang digunakan yaitu analisis kualitatif.

\section{Hasil Dan Pembahasan}

\subsection{Pengaturan Pecandu dan Penyalah Guna Narkotika dalam Undang-Undang No. 35 Tahun 2009 Tentang Narkotika}

Secara etimologis asal mula dari kata narkotika adalah narke atau narkam yang asalnya dari bahasa Yunani. "Narke" atau "narkam" itu sendiri memiliki makna terbius sehingga tidak merasakan apa-apa. ${ }^{6}$ Pada Kamus Besar Bahasa Indonesia atau yang lebih mudah disebut sebagai KBBI, menggunakan kata narkotik yang memiliki definisi sebagai "obat untuk menenangkan saraf, menghilangkan rasa sakit, menimbulkan rasa mengantuk". Berdasarkan kedua pengertian mengenai narkotika tersebut maka dapat diketahui bahwa selain fungsinya dapat menimbulkan efek yang positif namun dibalik itu juga memiliki dampak negatif. Dampak positifnya bisa membantu di dalam dunia pengobatan yang pada intinya memberikan efek tenang kepada pasien. Dampak negatifnya apabila digunakan tanpa pengawasan dan sembarangan yang nantinya dapat menimbulkan kecanduan yang berlebihan akibat penggunaan yang salah. Pelaku

4 Soekanto, S. \& Mamuji S., Penelitian Hukum Normatif Suatu Tinjauan Singkat. (Jakarta: RajaGrafindo, 2010), 13-14.

5 Salim HS \& Nurbani, E. S., Penerapan Teori Hukum pada Penelitian Tesis dan Disertasi. Cet. III., (Jakarta: RajaGrafindo, 2014), 16.

6 Eleanora, F. N., "Bahaya Penyalahgunaan Narkoba Serta Usaha Pencegahan Dan Penanggulangannya (Suatu Tinjauan Teoritis)". Jurnal hukum, 25(1) (2019), 439-452. 
penyalahgunaan narkotika yang semakin tinggi sangat mengkhawatirkan bagi masyarakat. ${ }^{7}$

Definisi pecandu dan juga penyalah guna narkotika tercantum pada Pasal 1 angka 13 dan angka 15 UU 35/2009 yang pada intinya mengandung pengertian bahwa orang yang mengalami ketergantungan secara psikis ataupun fisik terhadap narkotika akibat dari menggunakan maupun menyalahgunakan benda tersebut disebut sebagai pecandu, sedangkan narkotika yang digunakan oleh seseorang dengan melawan hukum ataupun tanpa haknya menggunakan benda tersebut maka disebut sebagai penyalah guna narkotika. Bila dilihat dari kedua pengertian tersebut ada hal yang membedakan dan ada hal yang sama antara pecandu dengan penyalah guna narkotika. Hal yang sama antara keduanya adalah sesama menggunakan narkotika. Sedangkan, hal yang membedakan adalah dalam pengertian pecandu terdapat kata "atau" yang berarti dapat menjadi pecandu dalam dua kondisi yaitu apabila menggunakan atau menyalahgunakan. Kondisi menggunakan narkotika hingga menjadi pecandu berarti pada awalnya ia mengunakan narkotika tanpa melawan hukum, dengan kata lain ia mendapatkan narkotika dari dokter untuk proses pengobatan. Namun, karena digunakan secara terus menerus maka ia akan menjadi ketergantungan. Berbeda halnya dengan pecandu yang menyalahgunakan narkotika, yang artinya sejak awal ia telah mendapatkan narkotika dengan melawan hukum hingga menyebabkan ketergantungan. Kemudian, penyalah guna narkotika tidak selalu sebagai pecandu. Asalkan telah menggunakan narkotika dengan melawan hukum walaupun saat itu pertama kali menggunakannya akan tetap disebut sebagai penyalah guna narkotika.

Pengaturan pecandu dan penyalah guna narkotika terdapat di dalam UU 35/2009. Pengaturan mengenai pecandu dan penyalah guna merupakan satu dari 4 (empat) tujuan dibentuknya undang-undang ini, hal itu tercantum pada Pasal 4 huruf d yang dimana pecandu beserta dengan para penyalahguna narkotika dijamin agar diupayakan diberikan suatu tindakan berupa tindakan rehabilitasi, yang dimana rehabilitasi tersebut terdiri dari 2 jenis rehabilitasi yaitu yang pertama berupa rehabilitasi medis dan kemudian berupa pemberian tindakan rehabilitasi sosial. Ketentuan tersebut memberikan kepastian kepada para pecandu beserta dengan para penyalahguna narkotika akan dijamin undang-undang dalam upaya mendapatkan suatu tindakan berupa rehabilitasi medis yang dilanjutkan dengan rehabilitasi sosial. Rehabilitasi terhadap pecandu narkotika adalah suatu proses pengobatan untuk membebaskan pecandu dari ketergantungan. ${ }^{8}$

Secara singkat, rehabilitasi medis adalah pengobatan sedangkan rehabilitasi sosial adalah pemulihan. Dalam pengobatan dilakukan suatu kegiatan agar pecandu nantinya terbebas dari rasa ketergantungan terhadap narkotika. Kemudian, dalam pemulihan dilakukan suatu kegiatan agar mental, fisik dan juga sosialnya dipulihkan kembali untuk siap kembali ke masyarakat. Jadi, rehabilitasi medis merupakan pengobatan agar pecandu bisa sembuh dari rasa kecanduannya terhadap narkotika karena tujuan dari pengobatan adalah kesembuhan, kemudian dilanjutkan pemberian rehabilitasi sosial agar mereka yang telah selesai diobati dalam proses pengobatan dan telah sembuh

7 Laksana, A. W. (2016). Tinjauan Hukum Pemidanaan Terhadap Pelaku Penyalahguna Narkotika Dengan Sistem Rehabilitasi. Jurnal Pembaharuan Hukum, 2(1), 74-85.

8 Putu Indra Arditya Putra I Made Tjatrayasa, Darmadi, AA Ngurah Yusa. "Pelaksanaan Rehabilitasi terhadap Pecandu Narkotika oleh Badan Narkotika Nasional Provinsi Bali di Denpasar, Kertha Wicara, E-Journal Ilmu Hukum Vol. 6 No. 1 (2017), 1-5. 
dapat kembali ke masyarakat dengan baik melalui proses pemulihan kehidupan sosialnnya.

Pengobatan dan rehabilitasi terhadap pecandu dan penyalah guna narkotika diatur khusus pada BAB IX mengenai Pengobatan dan Rehabilitasi, terdiri dari 7 (tujuh) pasal, mulai dari Pasal 53 hingga Pasal 59. Pengkhususan bab tersebut dengan permasalahan tersebut menunjukkan bahwa pemerintah sudah sadar dan peduli terhadap pecandu beserta korban penyalah guna narkotika karena mereka diberikan sanksi berupa rehabilitasi. ${ }^{9}$ Diantara ketujuh pasal tersebut terdapat ketentuan yang lebih menegaskan kepada pecandu beserta korban penyalah guna narkotika diwajibkan untuk mendapatkan rehabilitasi medis dan sosial tepatnya pada Pasal 54. Pada pasal tersebut dikemukakan kata baru yaitu "korban" penyalah guna narkotika, tentunya hal tersebut memiliki pengertian yang berbeda dengan penyalah guna narkotika saja. Apabila terjadi ketidaksengajaan dalam penggunaan narkotika karena bukan dari kehendak diri sendiri maka seseorang tersebut disebut sebagai korban penyalah guna narkotika. Bukan kehendak diri sendiri tersebut terdiri dari adanya unsur-unsur diperdaya, dibujuk, dipaksa, ditipu, dan/atau diancam oleh orang lain. Pada ketentuan ini ruang lingkupnya lebih dipersempit karena hanya korban penyalah guna narkotika yang wajib menjalani rehabilitasi medis dan sosial. Sedangkan, pada tujuan UU 35/2009 ruang lingkupnya lebih luas karena menyebutkan penyalah guna narkotika saja bukan korban penyalah guna narkotika. Jadi, seharusnya baik itu korban ataupun bukan mereka wajib diberikan rehabilitasi. Tidak hanya mengenai hal itu, namun pada bab tersebut juga diatur hal-hal lain, yaitu:

1. Narkotika golongan II maupun golongan III dapat diberikan oleh dokter kepada pasien secara terbatas untuk kepentingan pengobatan, pasien dapat memiliki narkotika tersebut harus memiliki bukti yang sah (Pasal 53).

2. Seorang pecandu apabila belum cukup umur, yang bertanggungjawab untuk melaporkan ke instansi-instansi kesehatan seperti rumah sakit adalah orang tuanya jika tidak ada maka dapat walinya yang melaporkannya. Tetapi, bila seorang pecadu sudah cukup umur maka dirinya sendiri yang wajib melapor ke instansi-instansi kesehatan tersebut (Pasal 55).

3. Peran Menteri menunjuk rumah sakit dan memberikan izin kepada lembaga rehabilitasi tertentu untuk melakukan rehabilitasi medis (Pasal 56).

4. Penyembuhan pecandu dapat menggunakan pendekatan tradisional dan keagamaan yang dapat dilakukan oleh baik instansi pemerintah maupun dari masyarakat itu sendiri (Pasal 57).

5. Penyelenggaraan rehabilitasi sosial dapat dilakukan oleh instansi pemerintah ataupun juga oleh masyarakat (Pasal 58).

6. Pasal 59 mengatur ketentuan pelaksana pada Pasal 56, Pasal 57, dan 58 diatur pada peraturan menteri.

Demi mendapatkan haknya sebagai pecandu narkotika maka dibentuklah suatu peraturan yaitu Peraturan Pemerintah Nomor 25 Tahun 2011 tentang Pelaksanaan Wajib Lapor Pecandu Narkotika. Tujuan dibentuknya peraturan ini yaitu untuk memenuhi hak pecandu narkotika dalam mendapatkan pengobatan dan/atau perawatan melalui rehabilitasi medis dan rehabilitasi sosial; mengikutsertakan orang tua, wali, keluarga,

${ }^{9}$ Diputra, I. B. P. S. Op. Cit., 9. 
dan masyarakat dalam meningkatkan tanggung jawab terhadap pecandu narkotika yang ada di bawah pengawasan dan bimbingannya; dan memberikan bahan informasi bagi Pemerintah dalam menetapkan kebijakan di bidang pencegahan dan pemberantasan penyalahgunaan dan peredaran gelap narkotika.

Wajib lapor tersebut mengandung definisi merupakan kegiatan melaporkan diri yang dilakukan oleh pecandu narkotika yang sudah cukup umur atau keluarganya, dan/atau orang tua atau wali dari pecandu narkotika yang belum cukup umur kepada institusi penerimaan wajib lapor untuk mendapatkan pengobatan dan/atau perawatan melalui rehabilitasi medis dan rehabilitasi sosial. Definisi tersebut tercantum pada Pasal 1 angka 1 Peraturan Pemerintah Nomor 25 Tahun 2011 tentang Pelaksanaan Wajib Lapor Pecandu Narkotika. Pecandu narkotika yang telah melaksanakan wajib lapor wajib menjalani rehabilitasi medis dan/atau rehabilitasi sosial sesuai dengan rencana rehabilitasi yang telah disepakati oleh pecandu narkotika, orang tua, wali, atau keluarga pecandu narkotika dan pimpinan Institusi Penerima Wajib Lapor.

\subsection{Ketentuan Pidana bagi Pecandu dan Penyalahguna Narkotika dalam UU 35/2009}

Penyalah guna narkotika dapat diberikan sanksi pidana penjara berdasarkan pengaturan pada Pasal 127 ayat (1). Masa hukuman penjara berbeda-beda tergantung dari penyalahgunaan narkotika itu sendiri berdasarkan per golongan yaitu golongan I, II, atau III. Penyalah guna narkotika golongan I akan dikenakan penjara maksimal empat tahun. Penyalah guna narkotika golongan II akan dikenakan penjara maksimal dua tahun. Sedangkan, penyalah guna narkotika golongan III dikenakan penjara maksimal satu tahun. Namun pada ayat (3), penyalah guna yang terbukti ataupun tidak terbukti sebagai korban penyalah guna wajib direhabilitasi medis dan rehabilitasi sosial.

Seorang pecandu narkotika yang telah memiliki umur yang cukup kemudian tidak melaporkan dirinya sendiri bahwa ia seorang pecandu ke Rumah Sakit, Lembaga Rehabilitasi, dan lain-lain sesuai dengan Pasal 55 ayat (2) maka dapat dikenakan kurungan maksimal hingga 6 (enam) bulan ataupun dikenakan denda, dimana denda maksimal yang dapat diberikan sebanyak Rp 1.000.000,00 (satu juta rupiah). Pengaturan tersebut diatur pada Pasal 134. Bila dilihat dari pengaturan yang telah diatur dalam ketentuan pidana bagi pecandu dan penyalah guna narkotika maka dapat dikenakan pidana yaitu penjara, kurungan, ataupun denda. Namun, hal itu harus memperhatikan ketentuan-ketentuan lainnya juga.

Pada UU 35/2009 kejahatan narkotika dikelompokan menjadi dua jenis kejahatan, yaitu kejahatan yang mengenai penyalahgunaan dan kejahatan yang mengenai peredaran gelap narkotika. Jika dilihat dari tujuan UU 35/2009 dan juga pengelompokan kejahatan narkotika tersebut maka dapat dikatakan bahwa Double Track System atau dapat disebut sebagai Sistem Dua Jalur dianut oleh undang-undang ini dalam sistem pemidanaan. Perkembangan sistem hukum inilah yang memperkenalkannya tindakan (maatregel) sebagai alternatif lain dari pidana pokok terutama pidana penjara. ${ }^{10}$ Kejahatan peredaran gelap narkotika dikenakan Criminal Justice System (CJS) sedangkan kejahatan penyalahgunaan narkotika dikenakan Rehabilitation Justice System (RJS). Pengedar dalam mempertanggungjawabkan perbuatannya melalui CJS bermuara di penjara, sedangkan penyalahguna dalam mempertanggungjawabkan perbuatannya melalui RJS bermuara di Lembaga

10 Ramadhani, G. S., \& Barda Nawawi Arief, P., "Sistem Pidana dan Tindakan "Double Track System" Dalam Hukum Pidana di Indonesia". Diponegoro Law Journal, 1(4) (2012). 
Rehabilitasi. ${ }^{11}$ "Berdasarkan hal tersebut double track system pada perumusan hukuman terhadap tindak pidana penyalahgunaan narkotika adalah paling benar, karena berdasarkan victimologi bahwa pecandu narkotika adalah sebagai self victimizing victims yaitu korban sebagai pelaku, victimologi tidak berubah menempatkan penyalahguna narkotika sebagai korban, walaupun dari kejahatan yang dilakukan oleh dirinya sendiri". ${ }^{12}$

Penjatuhan pidana kepada penyalahgunaan narkotika tidaklah menjadi keputusan yang tepat dalam upaya pemberantasan penyalahgunaan narkotika di kalangan penyalahgunanya. ${ }^{13}$ Sanksi pidana akan terlihat menjadi tidak berguna kalau dihubungkan dengan pemulihan terhadap ketergantungan dan efek narkotika tersebut pada orang yang menggunakannya. 14 "Pecandu narkotika dan juga korban penyalahgunaan narkotika yang terkena operasi tangkap tangan atau biasa disebut sebagai OTT baik tanpa barang bukti dan bahkan terdapat barang bukti dengan jumlah tertentu maka ia dapat ditempatkan pada lembaga rehabilitas dengan panduan Berita Acara Pemeriksaan Laboratorium, Berita Acara Pemeriksaan oleh Penyidik dan dilengkapi dengan Surat Hasil Rekomendasi Tim Asesmen Terpadu yang sebelumnya telah diajukan oleh penyidik ke Badan Narkotika Nasional". ${ }^{15}$

Hakim yang mempunyai tugas untuk memberikan putusan harus melihat ketentuan-ketentuan yang berlaku. Berdasarkan Pasal 103 ayat (1), mengatur ketentuan yang intinya menyatakan hakim dapat memutus agar pecandu diberikan pengobatan apabila terbukti bersalah serta hakim dapat menetapkan memberikan pecandu pengobatan apabila terbukti tidak bersalah melakukan tindak pidana narkotika. waktu yang diberikan sebagai masa pengobatan yang telah diputuskan ataupun ditetapkan oleh hakim merupakan ganti dari masa hukuman pecandu narkotika tersebut berdasarkan ketentuan yang disebutkan pada Pasal 103 ayat (2). Jadi, masa pengobatan sama dengan sebagai masa hukuman bagi pecandu tersebut.

Detail konstruksi Rehabilitasi Justice System (RJS) dalam UU 35/2009, yaitu:16

1. Tujuan UU 35/2009 Pasal 4 adalah melakukan pencegahan, memberikan perlindungan, dan menyelamatkan bangsa Indonesia dari penyalahgunaan narkotika serta menjamin pengaturan untuk penyalah guna dan juga pecandu agar dijamin diberikan rehabilitasi total baik medis maupun sosial. Berbeda halnya dengan pengedar yang harus diberantas.

2. Pada tiga pasal yaitu Pasal 127, Pasal 134, dan penjelasan Pasal 54, diancam hukuman pidana paling ringan 4 tahun bagi kelompok penyalah guna. Artinya:

11 Iskandar, A., Penegakan Hukum Narkotika. (Jakarta: Elex Media Komputindo, 2019). 48.

12 Candra Dewi, A., "Perlindungan Hukum terhadap Korban Penyalahguna Narkotika dengan Berlakunya Undang-Undang Nomor 35 Tahun 2009 tentang Narkotika". Jurnal Magister Hukum Udayana (Udayana Master Law Journal), 1(1) (2012).

13 Sugiarto, S., "Penjatuhan Pidana oleh Hakim Terhadap Prajurit Tentara Nasional Indonesia sebagai Pelaku Penyalahguna Narkotika." Jurnal Magister Hukum Udayana (Udayana Master Law Journal), 7(2) (2018), 165-176.

14 Afrizal, Riki, and Upita Anggunsuri. "Optimalisasi Proses Asesmen terhadap Penyalah Guna Narkotika dalam Rangka Efektivitas Rehabilitasi Medis dan Sosial Bagi Pecandu Narkotika." Jurnal Penelitian Hukum De Jure 19, no. 3 (2019): 259-268.

15 Rizky, F.Op.Cit.,109.

16 Iskandar, A. Op.Cit., 49. 
a. Secara hukum acara pidana kelompok penyalahguna tidak memenuhi syarat subjektif untuk ditahan baik itu pada tahap penyidikan, atau pada tahap penuntutan, bahkan saat peradilan pun juga tidak dapat ditahan. Kelompok penyalah guna itu sendiri terdiri dari pecandu, penyalah guna itu sendiri, kemudian korban penyalahgunaan narkotika.

b. Apabila dilihat dari tujuan UU 35/2009 dengan demikian kelompok penyalah guna tersebut harus dipisah dari kelompok lainnya yaitu kelompok pengedar narkotika pada saat disidik, dituntut dan diadili karena kelompok penyalahguna dijamin untuk direhabilitasi saat melalui proses penyidikan, kemudian proses penuntutan, dan juga saat proses peradilan. Sementara itu, kelompok pengedar diberantas.

c. Kecuali kalau kelompok penyalahguna dapat dibuktikan juga berperan menjadi pengedar, hingga memperoleh suatu keuntungan dari bisnis yang dijalankan berupa peredaran gelap narkotika, artinya berpredikat ganda sebagai pengedar sekaligus sebagai penyalahguna.

3. Penyalahguna merupakan seseorang yang sedang dalam kondisi sakit, lebih tepatnya dimana mengalami kondisi kecanduan atau penyakit adiksi yang dapat sembuh atau kembali pulih bila direhabilitasi.

4. Penyalahguna apabila diproses untuk dipahami permasalahannya atau proses tersebut disebut dengan asesmen yang dilakukan oleh tim asesmen atau juga oleh dokter ahli, maka mereka yang awalnya sebagai penyalahguna saja dapat berubah predikatnya sebagai pecandu.

5. Penegak hukum dalam hal ini terdiri dari penyidik, kemudian Penuntut Umum, dan juga Hakim diberikan kewenangan untuk menjalankan tujuan dari undang-undang tepatnya UU 35/2009, yaitu penyalah guna dan juga pecandu dijamin diberikan rehabilitasi. Kewenangan tersebut sebagai pengganti kewenangan menahan, dimana secara tidak langsung memaksa mereka ditempatkan di lembaga rehabilitasi (Pasal 4 Peraturan Pemerintah Nomor 25 tahun 2005 tentang Pelaksanaan Wajib Lapor Pecandu Narkotika).

6. Kewenangan khusus diberikan kepada Hakim oleh UU 35/2009, apabila terbukti bersalah maka Hakim dapat memutuskan memberikan hukuman rehabilitasi, sedangkan apabila tidak terbukti bersalah maka Hakim dapat menetapkan memberikan tindakan rehabilitasi (Pasal 103 ayat (1)), kewenangan tersebut memiliki pengertian bahwa baik bersalah maupun tidak bersalah, dan juga baik terbukti maupun tidak terbukti maka mereka tetap harus diberikan rehabilitasi sebagai pengganti hukuman penjara.

7. Pemberian hukuman rehabilitasi kepada penyalah guna, kemudian kepada korban penyalah guna juga, serta kepada pecandu sesungguhnya tingkatannya sama dengan memberikan hukuman penjara (Pasal 103 ayat (2)), dengan mendapatkan manfaat yang lebih baik daripada hukuman penjara karena mereka diobati baik secara medis maupun secara sosialnya. 
8. Penyalah guna statusnya akan berubah sebagai pecandu saat diminta visum Et Repertum, kemudian mereka akan diwajibkan untuk direhabilitasi. Penyalah guna pemula bila terbukti sebagai korban maka wajib direhabilitasi juga. (Pasal 54).

Peraturan pelaksana dari Undang-Undang Narkotika tersebut yaitu Peraturan Pemerintah Nomor 25 Tahun 2011 tentang Pelaksanaan Wajib Lapor Pecandu Narkotika juga kembali menekankan bahwa pecandu narkotika baik mereka terbukti ataupun tidak terbukti melakukan tindak pidana narkotika wajib menjalani rehabilitasi medis dan/atau rehabilitasi sosial. Bahkan, selama pecandu tersebut sedang menjalani persidangan di pengadilan, mereka ditempatkan di lembaga rehabilitasi medis dan/atau rehabilitasi sosial bukannya di dalam rumah tahanan atau dititipkan di dalam lembaga pemasyarakatan.

Prosedur lebih jelas tentang bagaimana seorang pecandu, penyalahguna atau korban penyalahgunaan narkotika baik itu statusnya sebagai tersangka, terdakwa maupun terpidana untuk mendapatkan rehabilitasi medis dan melakukan wajib lapor terdapat pada Peraturan Menteri Kesehatan Nomor 50 Tahun 2015 tentang Petunjuk Teknis Wajib Lapor dan Rehabilitasi Medis Pecandu, Penyalahguna dan Korban Penyalahguna Narkotika. Peraturan Menteri Kesehetan tersebut mengatur salah satunya tentang bagaimana prosedur layanan terhadap pecandu, penyalahguna dan korban penyalahgunaan narkotika yang berstatus sebagai tersangka, terdakwa,dan juga terpidana. Pada prosedur layanan tersebut ada dua jenis tahapan yang diatur yaitu prosedur penyerahan dan juga tata laksana rehabilitasi medis.

Prosedur penyerahan bagi tersangka dan juga terdakwa dilakukan oleh penyidik atau penuntut umum didampingi oleh pihak keluarga dan pihak BNN/BNNP/BNNK (bergantung pada tingkat perkara dan Berita Acara tersangka), dengan melampirkan rekomendasi rencana terapi rehabilitasi dari Tim Asesmen Terpadu. Sedangkan, bagi terpidana prosedur penyerahannya dilakukan oleh pihak Kejaksaan ke fasilitas rehabilitasi medis yang ditunjuk dan disertai Berita Acara Penetapan/Putusan Pengadilan yang ditandatangani oleh petugas Kejaksaan, terpidana yang bersangkutan dan tenaga kesehatan yang menerima pasien, dengan melampirkan salinan/petikan surat penetapan pengadilan atau surat putusan pengadilan yang telah mempunyai kekuatan hukum tetap dan surat pernyataan kesanggupan dari terpidana yang telah ditandatangani oleh terpidana dan keluarga/walinya untuk menjalani rehabilitasi medis sesuai rencana terapi yang ditetapkan oleh tim dokter dan Tim Asesmen Terpadu dan mengikuti program yang berlaku pada fasilitas rehabilitasi.

Setelah tahap penyerahan maka akan dilakukan tata laksana rehabilitasi medis. Bagi tersangka atau terdakwa rehabilitasi medis dilakukan dengan cara rawat inap atau rawat jalan, sesuai dengan permintaan resmi tertulis pihak kepolisian, BNN/BNNP/BNNK (penyidik), atau kejaksaan (penuntut umum) yang didasarkan pada rekomendasi rencana terapi rehabilitasi dari Tim Asesmen Terpadu, untuk jangka waktu paling lama tiga bulan. Sedangkan, bagi terpidana mengikuti program rehabilitasi medis sesuai dengan program bagi pecandu dan korban penyalahgunaan narkotika yang datang secara sukarela. Hal tersebut dimaksudkan untuk menjamin terlaksananya program secara konsisten dan memberikan efek perubahan perilaku yang positif yang tidak berssifat diskriminatif. Terpidana wajib menjalani tiga tahap perawatan, yaitu program rawat inap, program lanjutan dan program pasca rawat. 
Teori utilitas (Utiliteis theory) mengemukakan, hukum mewujudkan kemanfaatan. Teori ini diajarkan oleh Jeremy Bentham. ${ }^{17}$ "Pada hakikatnya menurut teori ini tujuan hukum adalah manfaat dalam menghasilkan kesenangan atau kebahagiaan yang terbesar bagi jumlah orang yang terbanyak". ${ }^{18}$ Berdasarkan teori ini, hukum harus memberikan manfaat. Begitu pula dengan pecandu dan penyalahguna narkotika, pemberian sanksi terhadap mereka harus memberikan manfaat kepada mereka yaitu sanksi rehabilitasi.

Sanksi rehabilitasi memberikan manfaat yang lebih jelas dibandingkan dengan sanksi pidana. Pecandu dan penyalahguna narkotika adalah orang sakit dan mereka membutuhkan pertolongan agar dapat sembuh dan kembali ke dalam masyarakat. Pemberian sanksi tindakan rehabilitasi akan membantu terjadinya hal tersebut. Motif rehabilitasi untuk para pecandu narkotika adalah untuk kepentingan pemulihan (sembuh) dari narkotika bagi para pecandu dan korban. ${ }^{19}$ Guna terwujudnya pecandu dan penyalahguna narkotika yang mendapatkan haknya secara penuh untuk direhabilitasi maka ada baiknya undang-undang narkotika tersebut kedepannya dapat memberikan ketentuan-ketentuan secara jelas dan pasti sesuai dengan tujuan dibentuknya undang-undang tersebut, sehingga tidak ada kerancuan antara ketentuan satu dengan ketentuan yang lainnya. Selain itu, diperlukannya suatu ketentuan dalam peraturan turunan dari undang-undang narkotika mengenai program kerja lembaga rehabilitasi dan dibentuknya lembaga rehabilitasi hingga mencakup ke daerah-daerah yang lebih dalam guna mempermudah proses rehabilitasi bagi pecandu dan penyalahguna narkotika yang membutuhkan.

\section{Kesimpulan}

Berdasarkan pemaparan pada bagian hasil dan pembahasan, dapat disimpulkan bahwa Pecandu dan penyalah guna narkotika pengaturannya ada pada UU 35/2009, tepatnya pada Pasal 4 huruf d yaitu pecandu dan penyalah guna narkotika dijamin untuk mendapatkan rehabilitasi yang terdiri dari rehabilitasi medis dan juga rehabilitasi sosial. Selain itu, pengaturan Pasal 54 lebih menegaskan lagi kepada pecandu dan juga sebagai korban penyalahgunaan narkotika diwajibkan mendapatkan rehabilitasi medis dan rehabilitasi sosial. Pecandu dan penyalah guna dapat dikenakan pidana berdasarkan pengaturan yang diatur pada Pasal 134 dan Pasal 127 ayat (1) UU 35/2009. Namun, berdasarkan tujuan undang-undang tersebut, mewajibkan pecandu dan penyalah guna diberikan rehabilitasi medis dan rehabilitasi sosial. pemberian sanksi terhadap mereka harus memberikan manfaat kepada mereka yaitu sanksi rehabilitasi. Sanksi rehabilitasi memberikan manfaat yang lebih jelas dibandingkan dengan sanksi pidana. Pecandu dan penyalahguna narkotika adalah orang sakit dan mereka membutuhkan pertolongan agar dapat sembuh dan kembali ke dalam masyarakat.

\section{DAFTAR PUSTAKA}

\section{Buku}

Iskandar, A., Penegakan Hukum Narkotika. (Jakarta: Elex Media Komputindo, 2019).

17 Elias, R. F., "Penemuan Hukum dalam Proses Peradilan Pidana di Indonesia." Jurnal LPPM Bidang EkoSosBudKum, 1(1) (2014), 1-11.

18 Rizky, F.Op.Cit., 106.

19 Winanti, Atik. "Upaya Rehabilitasi terhadap Pecandu Narkotika dalam Perspektif Hukum Pidana." ADIL: Jurnal Hukum 10, no. 1 (2019). 
Salim HS \& Nurbani, E. S., Penerapan Teori Hukum pada Penelitian Tesis dan Disertasi. Cet. III., (Jakarta: RajaGrafindo, 2014), 16.

Soekanto, S., \& Mamuji, S., Penelitian Hukum Normatif Suatu Tinjauan Singkat. (Jakarta: RajaGrafindo, 2010).

Sudarto, Kapita Selekta Hukum Pidana, Cet. ke-IV, (Bandung, PT Alumni, 2010).

\section{Jurnal}

Afrizal, Riki, and Upita Anggunsuri. "Optimalisasi Proses Asesmen terhadap Penyalah Guna Narkotika dalam Rangka Efektivitas Rehabilitasi Medis dan Sosial Bagi Pecandu Narkotika." Jurnal Penelitian Hukum De Jure 19, no. 3 (2019): 259-268.

Arief, Barda Nawawi, and Gita Santika Ramadhani Purwoto. "Sistem Pidana dan Tindakan "Double Track System" dalam Hukum Pidana di Indonesia." Diponegoro Law Review 1, no. 4 (2012): 19518. Retrieved from https://ejournal3.undip.ac.id/index.php/dlr/article/view/612

Dewi, AA Istri Mas Candra. "Perlindungan Hukum terhadap Korban Penyalahguna Narkotika dengan Berlakunya Undang-undang Nomor 35 Tahun 2009 Tentang Narkotika." Jurnal Magister Hukum Udayana 1, no. 1 (2012): 44084. doi:10.24843/JMHU.2012.v01.i01.p01

Diputra, Ida Bagus Putu Swadharma. "Kebijakan Rehabilitasi terhadap Penyalah Guna Narkotika pada Undang Undang Nomor 35 Tahun 2009 Tentang Narkotika." Jurnal Magister Hukum Udayana 2, no. 1 (2013): 44098. doi:10.24843/JMHU.2013.v02.i01.p10

Eleanora, Fransiska Novita. "Bahaya Penyalahgunaan Narkoba Serta Usaha Pencegahan Dan Penanggulangannya (Suatu Tinjauan Teoritis)." Jurnal hukum 25, no. 1 (2020): 439-452.

Elias, Rodrigo Fernandes. "Penemuan hukum dalam proses peradilan pidana di Indonesia." Jurnal LPPM Bidang EkoSosBudKum 1, no. 1 (2014): 1-11.

Laksana, Andri Winjaya. "Tinjauan Hukum Pemidanaan Terhadap Pelaku Penyalahguna Narkotika Dengan Sistem Rehabilitasi." Jurnal Pembaharuan Hukum 2, no. 1 (2016): 74-85. DOI: http://dx.doi.org/10.26532/jph.v2i1.1417

Putu Indra Arditya Putra I Made Tjatrayasa, Darmadi, AA Ngurah Yusa. "Pelaksanaan Rehabilitasi terhadap Pecandu Narkotika oleh Badan Narkotika Nasional Provinsi Bali di Denpasar, Kertha Wicara, E-Journal Ilmu Hukum Vol. 6 No. 1 (2017), 1-5.

Rizky, Fauzi. "Pelaksanaan Rehabilitasi Terhadap Pecandu, Penyalahguna dan Korban Narkotika. "Riau Law Journal 1, no. 1: 103-123. DOI: http://dx.doi.org/10.30652/rlj.v1i1.4180

Sugiarto, S. (2018). Penjatuhan Pidana oleh Hakim Terhadap Prajurit Tentara Nasional Indonesia sebagai Pelaku Penyalahguna Narkotika. Jurnal Magister Hukum Udayana (Udayana Master Law Journal), 7(2), 165-176. doi:10.24843/JMHU.2018.v07.i02.p03

Winanti, Atik. "Upaya Rehabilitasi terhadap Pecandu Narkotika dalam Perspektif Hukum Pidana." ADIL: Jurnal Hukum 10, no. 1 (2019). DOI: https://doi.org/10.33476/ajl.v10i1.1069 


\section{Peraturan perundang-undangan}

Undang-Undang Nomor 35 Tahun 2009 tentang Narkotika (Lembaran Negara Republik Indonesia Tahun 2009 Nomor 143).

Peraturan Menteri Kesehatan Nomor 50 Tahun 2015 tentang Petunjuk Teknis Wajib Lapor dan Rehabilitasi Medis Pecandu, Penyalahguna dan Korban Penyalahguna Narkotika (Berita Negara Republik Indonesia Tahun 2015 Nomor 1146).

Pemerintah Nomor 25 Tahun 2011 tentang Pelaksanaan Wajib Lapor Pecandu Narkotika (Lembaran Negara Republik Indonesia Tahun 2011 Nomor 46). 